\title{
EEN KOM VOL GELUK
}

Museummensen breken zich over twee zaken dikwijls het hoofd: hoe kunnen zij de bezoeker met aandacht naar hun museumschatten laten kijken en hoe kunnen zij iets van de cultuurhistorische context van die voorwerpen aan de bezoekers overdragen. Precies deze twee zaken hebben Harriet Impey en Katie Pickwoad voor elkaar gekregen in het kinderboek Een Kom vol Geluk.

Dit is een zeer aantrekkelijk platen- en verhalenboek, met een ruim formaat (bijna $30 \mathrm{~cm}$. in het vierkant), waarin Kang, een kleine Chinese jongen, op zijn stokpaard op zoek gaat naar geluk. Kang is een figuurtje uit een vaas uit de Overgangsperiode uit de collectie van het Rijksmuseum en de steeds groeiende stoet dieren die Kang en Paard op hun tocht vergezellen zijn alle afkomstig van stukken porselein uit de collecties van dit museum en Museum Princessehof. Aan het begin en eind van het boek is een 'tableau de la troupe' afgedrukt, alle stukken porselein bij elkaar, zodat duidelijk is wie waar vandaan komt. Voor het verhaal en de illustraties hebben Pickwoad en Impey zowel de personages als landschapselementen en decoratieve patronen uit de afbeeldingen van dit porselein gehaald. Met deze elementen, gecombineerd met eigen tekenwerk dat op de porseleindecoraties is

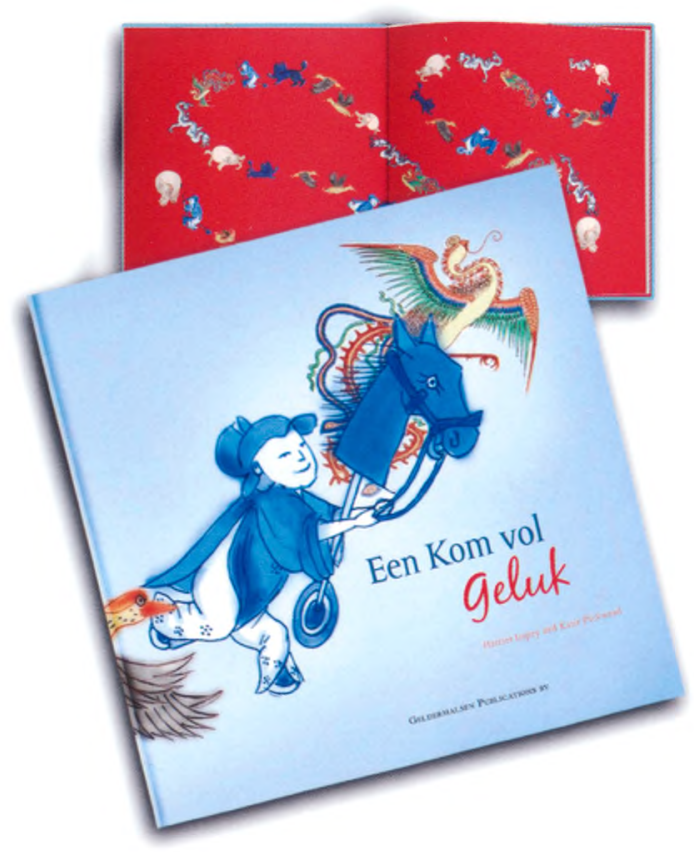


gebaseerd en er naadloos op aansluit, componeren zij steeds op een dubbele pagina prachtige scènes waarin het verhaal zich afspeelt. Ook wie denkt de stukken porselein goed te kennen, kan getroffen worden door de zeggingskracht van een detail op de manier waarop het hier getoond wordt.

Goed kijken gaat in dit boek dus min of meer vanzelf, maar de lezer wordt ook zonder problemen de wondere Chinese wereld ingeloodst, gevuld met gewone dieren en fabeldieren die onvermoede krachten hebben en die op hun reis terechtkomen in de Chinese oude verhalen die op het porselein zijn afgebeeld. Het zijn natuurlijk maar een paar dieren waarvan de betekenis wordt aangestipt en het zijn maar een paar verhalen die kort aan de orde komen, maar het is een uitstekende uitnodiging om ook bij andere stukken porselein je af te vragen wat de betekenis van de motieven zal zijn, wat voor verhalen er kunnen zijn afgebeeld. Kortom: het boek zet aan tot nieuwsgierigheid.

En hoe loopt het af met Kang, de hoofdpersoon van het boek? Wie het verschil ziet tussen de eerste keer dat de vaas is afgebeeld en de laatste keer, weet het antwoord. Goed kijken dus.

- Harriet Impey en Katie Pickwoad, Een Kom vol Geluk, Haren, Geldermalsen Publications, 2011, 28 pagina's volledig in kleur geïllustreerd, gebonden met een harde kaft, ISBN 978-90-72370-06-6, $€$ 19,95. De gelijktijdig uitgebrachte Engelse editie: A Bowlful of Happiness, ISBN 978-90-72370-06-8. 


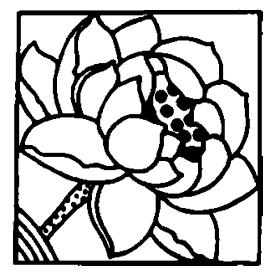

Vereniging van Vrienden der Aziatische Kunst www.vvak.nl

ERELID

Dr. J. Fontein

BESTUUR

Mr. J.M. Boll, voorzitter

Ir. A.A. Holst, lid

Mw. Ir. A.W. Leistra, lid

Mw. drs. R.H.M. van der Poel, secretaris

Mw. drs. R.E. Roskam, lid

Mr. R.R. Smit, penningmeester

RAAD VAN ADVIES

Mr. W.L.J. Bröcker

Mw. drs. A.J. Le Coultre-Foest

Prof.dr. C.J.A. Jörg

Drs. H.E. Kreijger

Mr. E.M.W. de Lange

Mr. drs. A. Ott

J. Polak

Mw. dr. C.E. van Rappard-Boon

J.J.N. Rost Onnes

Mw. dr. R.L. Steenbergen

CORPORATE MEMBER

Ottema Kingma Stichting Leeuwarden

\section{Lidmaatschap}

- Gewoon lidmaatschap: (tenminste) $€ 60$,per kalenderjaar

- Aspirant-lidmaatschap ( $t / m 25$ jaar): $€ 25$,per kalenderjaar

- Corporate member: $€ 600$,- per kalenderjaar

Het lidmaatschap van de Vereniging loopt van 1 januari tot en met 31 december. Opzegging van het lidmaatschap kan alleen schriftelijk via het bestuur (wak@denboerenvink.nl). Opzegging voor een komend jaar dienen vóor 31 december van het lopende jaar door het bestuur ontvangen te zijn. Wanneer het lidmaatschap in de loop van het verenigingsjaar wordt beëindigd, blijft de bijdrage voor het hele jaar verschuldigd.

\section{Als WVAK-lid}

- ontvangt $\mathrm{u}$ vier maal per jaar het tijdschrift Aziatische Kunst

- krijgt u ieder kwartaal de VVAK-Nieuwsbrief ir de bus

- wordt u uitgenodigd voor lezingen en bijeenkomsten

- krijgt u een lidmaatschapskaart, waarmee u gratis toegang heeft tot het Rijksmuseum Amsterdam en de activiteiten van de VVAK

\section{Ledenadministratie en secretariaat Vereniging} Jac's den Boer en Vink bv

Postbus 43

2850 AA Haastrecht

T: 0182501696

E: vvak@denboerenvink.nl

\section{Advertenties}

Om te adverteren in Aziatische Kunst kunt $u$ contact opnemen met de heer mr. R.R. Smit, penningmeester, e-mail: smitrr@planet.nl, telefoon: 0595557288.

Bankrekeningnummer

ING 188285 , ten name van Vereniging van Vrienden der Aziatische Kunst, Kantens.

\section{Kamer van Koophandel}

De Vereniging is ingeschreven bij de Kamer van Koophandel in Amsterdam, onder nummer 40.531 .260 .

\section{ANBI}

De Vereniging heeft de status van een Algemeen Nut Beogende Instelling. 